\title{
Liberal Philosophies of Ownership a
}

\author{
Stuart White
}

The Oxford Handbook of Mutual, Co-Operative, and Co-Owned Business

Edited by Jonathan Michie, Joseph R. Blasi, and Carlo Borzaga

Print Publication Date: Mar 2017

Subject: Business and Management, Organizational Theory and Behaviour, Finance and Economics

Online Publication Date: Nov 2017 DOI: 10.1093/oxfordhb/9780199684977.013.3

\begin{abstract}
Keywords
This chapter discusses three liberal philosophies of ownership: right libertarianism, which advocates an expansive conception of private property and which holds that legitimate and strict rights to such property can emerge through the voluntary production and exchange of self-owning individuals on the basis of initial privatizations of external resources that can be very unequal but nevertheless just; left libertarianism, which modifies the right libertarian position by insisting on a (more) egalitarian initial distribution of external resources; and democratic liberalism, which makes all property rights subject to democratic judgements guided by principles of social justice which express an understanding of citizens' common good. The chapter discusses the implications of each philosophy for cooperatives and mutuals and for the place of public policy in promoting these kinds of enterprises and related institutions.
\end{abstract}

Keywords: liberalism, property, ownership, rights, justice, democracy

\subsection{Introduction}

'LIBERALISM' is a capacious term. Liberals affirm the ideal of respect for free and equal personhood as the basis for legitimate authority and a just society. When it comes to thinking about the philosophy of ownership, however, it makes sense to think of there being a number of liberal philosophies based on different ways of interpreting this core ideal. My aim in this chapter is to set out in broad outline three philosophical perspectives on ownership within the liberal tradition. This treatment is far from exhaustive, but gives some indication of the range of possible liberal approaches.

I begin in Section 3.2 with an outline and brief discussion of the right libertarian philosophy of ownership. Section 3.3 elaborates the left libertarian philosophy of ownership. Section 3.4 presents the democratic liberal perspective. Each section sets out its re- 
spective philosophy of ownership in broad outline and then relates it specifically to co-operatives and mutuals. Section 3.5 concludes.

\subsection{Right Libertarianism}

Liberalism is frequently understood as affirming the inviolability of the individual based on rights. As Robert Nozick famously puts it: 'Individuals have rights, and there are things no person or group may do to them (without violating these rights)' (1974: ix). In Nozick's view, rights are properly seen as 'side constraints'. They set direct limits on how we may act towards others. On this view, we may not violate a person's rights even to prevent an even graver violation of rights (Sen 1982).

(p. 28) According to Nozick, when individuals acquire income and wealth through certain procedures, then these 'holdings' are held as rights in this sense. The moral requirement on us, and thus on the state, is to respect and protect these rights. If the state attempts to 'redistribute' income and wealth through taxes and income transfers, it violates the rights people have in their holdings. It necessarily acts unjustly.

How, though, do individuals come to hold income and resources by right in the first place? What process generates 'entitlements' in this sense? Nozick's account places a central emphasis on voluntary production and exchange. Imagine an initial distribution of holdings under which everyone has rights to what they hold. Through their voluntary production and exchange they create a new distribution of holdings. Provided that this new distribution emerges in a way that is voluntary-no force or fraud-then it is just. This captures the principle of justice in transfer (Nozick 1974: 150-3, 160-4). Nozick's view here is strongly opposed to the idea that we should assess justice in distributions by how far they satisfy some 'patterned' principle such as 'each according to desert' or 'each according to need' (Nozick 1974: 155-64). What matters, for justice, is not how far the distribution satisfies a structural principle of this kind, but how far it emerges from a prior just distribution in the right way (through voluntary production and exchange).

Justice in transfer, however, cannot be the whole story about how people acquire rights to holdings. If a distribution is just because it emerged in the right way from a prior distribution that itself was just, what made that distribution just? Logically, at some point, we have to explain the justice of some initial set of holdings in a way that doesn't invoke voluntary production and exchange from a prior distribution that is itself assumed to be just. We have to introduce a theory of original entitlements to complement the principle of justice in transfer.

Nozick's account of original entitlements draws heavily on the theory of property presented by John Locke in Chapter V of his Second Treatise of Civil Government (Locke 1965 [1690]). First, Nozick claims that each individual originally has full private property in their own body and abilities (Nozick 1974: 167-74). This is the thesis of self-ownership. Whereas Locke's account of self-ownership involves some moral limits (because we are, in the most fundamental sense, the property of God, and may not destroy or wilfully 
negate God's property), Nozick claims that each of us has unlimited rights over our body and abilities. These include, for example, the rights to hire out our labour-power or to sell our rights over our body and abilities, to another permanently, thereby becoming their slave.

Second, Nozick claims that there is a legitimate way in which external resources, such as land, can become private property. In Locke's account, individuals can acquire private property rights in these initially unowned external resources by mixing their self-owned labour with them, subject to the condition that they do not annex more than they can use without products going to waste, and that they leave 'enough, and as good' for others (Locke 1965 [1690]: Chapter V, Sections 27-34). ${ }^{1}$ Nozick has a lot of fun picking holes in (p. 29) Locke's labour-mixing idea, but he takes something from the spirit of Locke's 'enough, and as good' proviso. Specifically, Nozick claims that an act of privatization of an initially unowned resource is legitimate if it does not make anyone else worse off than they would be if external resources remained in their initially unowned state (Nozick 1974: $174-82) .^{2}$ If acts of privatization satisfy this condition-they are not harmful to anyone relative to the baseline of a world where all external resources remain unowned-we have what Nozick calls justice in acquisition.

So justice is generated by the establishment of valid ownership rights in the following way. Every person initially and fully owns their own body and abilities (self-ownership). People may also acquire full private property rights in initially unowned external resources, such as land. They do this when their privatization of a given external resource satisfies the above test for justice in acquisition. Once original entitlements have been established in this way, people then come to have rights in holdings through repeated actions of voluntary production and exchange (justice in transfer). If holdings are generated in an unjust way, for example through theft, then the rectification principle says that there must be appropriate rectification for this injustice (Nozick 1974: 152-3).

I have referred above to 'full' private property rights and this term needs explanation. In an extremely important article, Anthony Honoré argues that we can distinguish no fewer than eleven different 'incidents' that make up private ownership with respect to a resource (Honoré 1987). These are roughly as follows: (1) possession: exclusive physical control of the resource, implying no interference without permission; (2) use: personal use and enjoyment of the resource; (3) management: the power to decide how and by whom the resource is to be used, including power of contract; (4) income: the power to appropriate market returns on market deployments of the resource; (5) capital: the power to alienate the resource via sale or gift and to consume or destroy it; (6) security: immunity of expropriation of the resource; (7) transmission: power of bequest; (8) absence of term: no time limit fixed on holding of the resource; (9) harm prevention duty: the liberty to use the object is restricted by a duty not to harm others; (10) liability to execution: the resource can be taken from the owner in lieu of payment for the execution of her or his debts; and (11) residuarity: lesser interests in the resource return to the owner on their 


\section{Liberal Philosophies of Ownership}

termination (e.g. if you lease out a room you own to someone for six months, rights to the room return to you at the end of the six months).

Honoré's objective is the analytic one of understanding what we mean, or can mean, by private property. He does not assert that all ownership relations must take the form of full private property, involving all eleven incidents. Nozickian property rights, however, (p. 30) are typically understood to be 'full' in the sense of involving all eleven incidents. Taken together, the forgoing principles, conjoined to this specific conception of private property, amount to one, particularly influential example of a right libertarian theory of economic justice.

To be clear, full private ownership rights constitute the legal baseline in this theory, but individuals are free to pool their resources in communes or worker-owned co-operatives if they wish. Nozick comments that worker-owned co-operatives might be less efficient than capitalist firms, but that even if this is so, they might arise if workers and/or consumers are willing to pay for them in the form of lower wages and/or higher prices (Nozick 1974: 250-3). ${ }^{3}$ What is not acceptable, however, is to use state authority to require the co-operative form or to subsidize it. These measures would violate individuals' baseline private property rights.

Nozick's right libertarian theory has stimulated great controversy. It apparently allows for the emergence of significant economic inequality and poverty while ruling out the 'redistribution' that would mitigate them. Critics have identified a number of problems with the theory.

A first problem concerns the movement from theory to practice. Although the theory might show that a highly unequal capitalist society could be just in principle, it does not imply that any actually existing unequal capitalist society is just. This is because existing capitalist societies have been constructed on the basis of massive rights violations-enslavements, land grabs, and genocides-which have rarely, if ever, been subject to any adequate rectification. For the theory to have any real applicability to us, in our world shaped by enclosure and imperialism, we would first have to make appropriate rectification for historic injustices of these kinds (assuming such a thing is possible).

A second problem, internal to the theory, concerns the treatment of justice in acquisition. Nozick's account requires that nobody is harmed relative to the baseline world in which external resources remain unowned. But this criterion can be questioned on a number of grounds (G. A. Cohen 1995: Chapter 3). Perhaps most fundamentally, critics have asked why we should take the relevant baseline to be one in which all external resources are assumed to be unowned. Alternatively, for example, we could assume that the world is initially jointly owned (G. A. Cohen 1995: Chapters 3, 4). This means that nobody has an exclusive title to any external resource but also that use of any given resource requires the permission of everyone else, conceived as one of its joint owners. The distribution of welfare in this jointly owned world is likely to be different from that in the world where external resources are initially unowned. For example, those with limited productive capacity might be able to secure a higher level of welfare by using their power to withhold permis- 
sion to use resources to bargain for a share of what the (p. 31) more productively capable produce. In this respect, joint ownership seems to imply a higher welfare threshold for legitimate privatization.

What this discussion points up is the essential ambiguity of the Nozickian approach to justice in initial acquisition. It is all very well saying that acquisition is legitimate when it makes nobody worse off, but what is the correct baseline against which to make the assessment of harm? Insofar as this remains unclear, so, too, does the legitimacy of any initial acquisition; and without a clear account of this, uncertainty applies to every claimed 'entitlement' (G. A. Cohen 1995: Chapter 3; Wolff 1991: 112-15).

\subsection{Left Libertarianism}

One weak point in right libertarianism, then, is its account of how people come to have legitimate private ownership of parts of the external world. Left libertarianism retains much of the framework of right libertarianism, but breaks with it on precisely this point (Steiner 1994; Vallentyne and Steiner (eds.) 2000).

In its simplest version, left libertarianism replaces Nozick's principle of justice in acquisition with a principle of equal division. When it comes to external resources, such as land, each individual has a right to an equal share. For purposes of implementation, this is often conceived as a right to an equal share of the market value of these resources. We are to think of the community as the fundamental owner of the resources. Individuals may pay the community to gain certain use-rights over them. The community might acquire this payment through an appropriate tax on the value of the resource (George 2009 [1881]) or through something like a commercial rental arrangement. The community consolidates these payments into a central fund and distributes them to citizens. One possibility is to use the fund to pay for public services, for example universal education. Another is to distribute the fund to citizens as cash, either in the form of a periodic income grant (a basic income) or as a one-off lump sum (e.g. a capital grant on reaching adulthood as proposed by Paine 1987 [1797] and Ackerman and Alstott 1999).

On the left libertarian view, the state still remains unjustified in adopting any general 'redistribution'. A just distribution, which the state may not tamper with without violating individuals' rights, is one that emerges from voluntary production and exchange from a position of justice in original entitlements. These just original entitlements include, as for the right libertarian, universal self-ownership. But they also include the right to an equal share of external resources implemented in the form of universal public services or a universal cash grant financed from an appropriate fee levied on those who use external resources.

There are many questions about the details of the left libertarian approach. Which resources count as external resources for purposes of the equal division principle? There is general agreement that natural resources count. But what about wealth produced by pre- 


\section{Liberal Philosophies of Ownership}

vious generations? Do 'job assets' count as external resources in the relevant sense (Van Parijs 1995: Chapter 4)?

(p. 32) In addition, not all left libertarians accept that equal division is the correct approach. Michael Otsuka argues for what one might call compensatory division (Otsuka 2003: Chapter 2). Recall that left libertarians affirm universal self-ownership. This means they regard each person as (initially) the rightful owner of their own body and abilities. Self-owning individuals might have radically unequal abilities to earn income and wealth. As a full self-owner, however, no individual is required to share the market-contracted fruits of their abilities with others (unless they make a contract to this effect). So universal self-ownership is consistent with, and may work to reinforce, a highly unequal distribution of labour income (which, in turn, can obviously translate through saving into inequalities in wealth and in capital income). Otsuka argues that original entitlements in external resources should be set to compensate for inequalities in self-owned capacities. At this point the left libertarian perspective starts to overlap with the democratic liberalism I will discuss in Section 3.4, though the left libertarian perspective retains a distinctive emphasis on somehow using rights over external resources to promote egalitarian distributional objectives rather than transfers derived from direct taxation of labour incomes (Fried 2004).

So far as co-operatives and mutuals are concerned, left libertarianism takes fundamentally the same view as right libertarianism. If people wish to establish co-ops or mutuals, they have every right to do so. However, the state may not require this particular form of enterprise, nor subsidize it. In practice, however, left libertarianism will likely be more favourable to co-ops and mutuals than right libertarianism. Some argue that workerowned firms are likely to be more productively efficient than equivalent capitalist firms (Bowles and Gintis 1998: 36-9). ${ }^{4}$ However, against a background of wealth inequality and credit market imperfections, workers find it difficult to get the capital needed to start a firm of their own (Bowles and Gintis 1998: 39; Hoff 1998). A left libertarian regime would apparently be better than a right libertarian regime in this respect. If, say, the equal division principle is applied in the form of a basic income or basic capital, then workers will have resources which will make it easier to gain credit to start co-ops. We would then expect to see more of them, particularly if they do have a net efficiency advantage.

\subsection{Democratic Liberalism}

Let us turn now to democratic liberalism. To understand this liberalism it helps to begin with the idea of a deliberative democracy. I will work here with a very basic account of the idea. ${ }^{5}$ A political community is legitimate in its use of state power, according to this (p. 33) basic account of deliberative democracy, when certain conditions hold. The use of state power must be authorized by-laws which are themselves made in a sufficiently open, egalitarian, and contestable way. This implies a substantial set of civil and political rights to support egalitarian and contestatory political participation. In addition, the use of state power must be authorized by-laws that reflect deliberated judgements about 


\section{Liberal Philosophies of Ownership}

what best secures the citizenry's common good. By common good here we mean, centrally, the shared basic interests that citizens have, such as interests in life, liberty, equal civic standing, and economic opportunity. Laws should express judgements about what best secures these shared basic interests.

What does this require? A great deal of 'liberal egalitarian' political philosophy aims to provide an answer to this question by identifying relevant principles of justice. A very influential example is John Rawls's theory of justice (Rawls 1999 [1971], 2001). Rawls's theory is an attempt to give democratic citizens guidance, in the form of principles of justice, on what it would mean to show equal consideration for their shared basic interests (J. Cohen 2003).

The subject of a theory of justice is what Rawls calls the basic structure: roughly, the set of institutions which fundamentally affects how society distributes the benefits and burdens that affect citizens' shared basic interests. It encompasses political institutions, but also economic institutions including, most importantly, the system of property rights. The picture we are often given in contemporary political debate is one in which market-generated inequalities of income and wealth are presented as presumptively just, and movements away from this distribution, through taxation and transfers, face the burden of justification. For Rawls and other democratic liberals this gets things badly wrong (Murphy and Nagel 2002). The right kind of economic system is an open question, and we must approach it as such, asking in an open-minded way what system will best secure our common good by satisfying what we take to be the relevant principles of justice.

Rawls famously argues for a conception of justice he terms justice as fairness which consists of two principles:

(a) Each person has the same indefeasible claim to a fully adequate scheme of equal basic liberties, which scheme is compatible with the same scheme of liberties for all; and

(b) Social and economic inequalities are to satisfy two conditions: first, they are to be attached to offices and positions open to all under conditions of fair equality of opportunity; and second, they are to be to the greatest benefit of the least-advantaged members of society (the difference principle). (Rawls 2001: 42-3)

Rawls argues that the first principle has a strict ('lexical') priority to the second; and that, within the second principle, fair equality of opportunity has priority over the difference principle. This conception of justice has liberal content in the emphasis it gives to certain 'basic liberties' and their priority. These include freedom of conscience, expression, and association, and political rights to vote and stand for elected office. So far as (p. 34) political rights are concerned, the first principle also requires that the basic structure uphold their 'fair value', meaning that citizens of equal ability and motivation have equal opportunity to influence government regardless of their social class (Rawls 2001: 46). For Rawls, however, private property in productive resources is not in the set of basic liberties. In addition, in contrast to right and left libertarians, Rawls does not view self-ownership as among, or entailed by, these liberties. Our basic liberties include rights of bodily 


\section{Liberal Philosophies of Ownership}

integrity and freedom of occupational choice, but not the full set of rights constitutive of self-ownership. ${ }^{6}$ Setting up a property rights system which includes taxation of labour incomes violates the libertarian principle of self-ownership, but is not a violation of the basic liberties.

Rawls's conception of justice is also liberal and, in one sense, egalitarian in affirming fair equality of opportunity. This centrally requires that institutions work to even out chances of occupational attainment across people from different socio-economic backgrounds (Rawls 2001: 43-4). The difference principle adds another egalitarian dimension. It requires that socio-economic inequalities, such as in income and wealth, be arranged so that they are to the maximum benefit of the worst-off group (which Rawls thinks of as the class of workers in, or available for, full-time employment with the lowest earnings prospects). ${ }^{7}$

On Rawls's view, our society's economic structure is to be settled by democratic choice after considering what institutions will work to secure the principles of justice. Key questions to ask are:

(1) What sort of economic structure will work to maintain the first principle of justice, including the fair value of the political liberties?

(2) What sort of economic structure will work to secure fair equality of opportunity?

(3) What sort of economic structure will satisfy the difference principle?

Some have argued that a free-market capitalist economic structure will best satisfy principles such as these (Tomasi 2012). Rawls himself, however, claims that they are not well served either by a laissez-faire capitalist economy or by a command economy form of socialism. Nor does a system of 'welfare-state capitalism' go far enough, in Rawls's view, to satisfy these principles. welfare-state capitalism provides ameliorative assistance for those who lose out in market competition, but to really satisfy these principles more must be done to equalize citizens' claims over underlying assets. This might take the form of a 'property-owning democracy', which uses inheritance taxes and other (p. 35) measures to disperse privately owned wealth; or 'liberal socialism', which combines market allocation with public ownership of productive assets; or some hybrid of the two (Rawls 1999: 23442, 2001: 135-40). Rawls contrasts property-owning democracy with welfare-state capitalism as follows:

the background institutions of property-owning democracy, with its system of (workably) competitive markets, tries to disperse the ownership of wealth and capital, and thus to prevent a small part of society from controlling the economy and indirectly political life itself. Property-owning democracy avoids this, not by redistributing income to those with less at the end of each period, so to speak, but rather by ensuring the widespread ownership of productive assets and human capital ... at the beginning of each period.... The idea is not simply to assist those who lose out through accident or misfortune (although this must be done), but instead to put all citizens in a position to manage their own affairs and to take part in so- 


\section{Liberal Philosophies of Ownership}

cial cooperation on a footing of mutual respect under appropriately equal conditions.

(Rawls 1999: xv)

What does this framework imply for co-ops and mutuals? Rawls references John Stuart Mill's 'idea of worker-managed cooperative firms', commenting that this is 'fully compatible with property-owning democracy' (Rawls 2001: 176). In his Principles of Political Economy, Mill speculates hopefully that a general tendency towards reduced 'dependence' in social relationships will express itself in the gradual replacement of conventional capitalist firms by 'partnership, in one of two forms: in some cases, association of the labourers with the capitalist; in others, and perhaps finally in all, association of labourers among themselves' (Mill 1970 [1848]: 129). Referencing Mill's hopes, Rawls acknowledges that this hasn't happened, and poses some questions as to why it hasn't and whether a liberal state should promote Mill's idea (Rawls 2001: 178). Broadening the question a little, should a liberal state promote co-ops, mutuals, or similar institutions (e.g. enterprise democracy requirements)?

Note first that even if a liberal state does not purposively promote co-ops and mutuals, the relatively egalitarian distribution of wealth in a property-owning democracy might facilitate their formation relative to a right libertarian or similar basic structure. Again, the interaction between wealth distribution and credit markets could be important here.

Turning to active promotion of co-ops, mutuals, and related institutions, recall that liberalism is embedded here within a deliberative theory of democracy. The background supposition is of a citizenry concerned to legislate a basic structure according to informed judgements of the common good. But this, in turn, requires that citizens have a capacity and willingness for deliberative political participation. Imagine that enterprise democracy impacts positively on wider democratic citizenship (Pateman 1970). Then, as Rawls suggests, there could be a case for actively promoting democratic enterprises so as to secure the kind of political capacity and participation that deliberative democracy requires. ${ }^{8}$

(p. 36) Another possibility is that specific mutualistic forms of enterprise are in some way better suited to the economic interests of the worst-off (narrowly construed). For example, Martin Weitzman and James Meade have argued that certain very specific forms of profit- and revenue-sharing generate higher and more stable levels of employment relative to an otherwise equivalent capitalism in which workers are paid a fixed wage (Weitzman 1984; Meade 1989). If so, then a liberal state might have grounds to promote these forms of enterprise to satisfy the difference principle.

Third, if, as Rawls intends, one understands the position of the worst-off to be a matter of power and status, not only income and wealth, then a system that structures economic inequalities to the maximum benefit of the worst-off might well be one that places limits on acceptable inequalities of power and status within the enterprise. ${ }^{9}$ This might ground a 


\section{Liberal Philosophies of Ownership}

case for forms of 'workplace republicanism' (Hsieh 2005), or possibly employee ownership.

Finally, there might be contextual arguments for promoting co-ops and mutuals. Democratic liberals might wish to see a wider dispersion of wealth and, in principle, be indifferent as to how far this involves wider adoption of co-ops and mutuals. But starting from the situation in particular societies at particular times, it could be that promotion of coops and mutuals is the economically or politically most promising way towards the underlying goal of a more egalitarian distribution of wealth.

\subsection{Conclusion}

When we are asked to define liberalism's philosophy of ownership we must ask: which liberalism? Right libertarianism points to a society with potentially highly unequal amounts of private property, emerging through voluntary production and exchange, where the default ownership form is full private ownership in the sense clarified by Honoré. Left libertarianism qualifies this picture by insisting on a platform of initially equal external resource entitlements that are independent of voluntary production and exchange.

Democratic liberalism situates the question of property rights as a matter of democratic judgement of the common good, guided by principles of social justice. What follows from this perspective for ownership relations depends both on the exact specification of the principles and on what empirical research suggests is necessary or helpful to satisfy them. There is room for reasonable disagreement on both. It is therefore much harder to generalize about the sort of property relations supported by this perspective. John Rawls, a leading theorist of democratic liberalism, argues that justice requires either propertyowning democracy, liberal socialism, or a hybrid of the two. This points towards an economy in which there is considerable collective effort to shape the (p. 37) distribution of wealth and possibly also a significant degree of common ownership. This might provide an environment conducive for co-ops and mutuals to form; and there might also be arguments from within this framework to support deliberate promotion of these kinds of enterprises and related institutions.

\section{References}

Ackerman, Bruce and Alstott, Anne (1999), The Stakeholder Society (New Haven: Yale University Press).

Anderson, Elizabeth (1999), 'What is the Point of Equality?' Ethics, 109, 287-337.

Bowles, Samuel and Gintis, Herbert (1998),'Efficient Redistribution: New Rules for Markets, States and Communities', in S. Bowles and H. Gintis, with Erik Olin Wright, eds, Recasting Egalitarianism: New Rules for Communities, States and Markets (London: Verso), 3-71. 


\section{Liberal Philosophies of Ownership}

Carter, Neil (2006), 'Political Participation and the Workplace: The Spillover Thesis Revisited', British Journal of Politics and International Relations, 8(3), 410-26.

Christman, John (1991), 'Self-Ownership, Equality and the Structure of Property Rights', Political Theory, 19, 28-46.

Cohen, G. A. (1995), Self-Ownership, Freedom and Equality (Cambridge: Cambridge University Press).

Cohen, Joshua (2003), 'For a Democratic Society', in Samuel Freeman, ed., The Cambridge Companion to Rawls (Cambridge: Cambridge University Press), 86-138.

Cohen, Joshua (2009 [1989]), 'Deliberation and Democratic Legitimacy', in Joshua Cohen, Philosophy, Politics, Democracy (Cambridge, MA: Harvard University Press), 16-37.

Freeman, Samuel (2007), Rawls (Abingdon: Routledge).

Fried, Barbara, (2004), 'Left Libertarianism: A Review Essay', Philosophy and Public Affairs 32(1), 66-92.

George, Henry (2009) [1881], Poverty and Progress: An Inquiry into the Cause of Industrial Depressions and of Increase of Want with Increase of Wealth; the Remedy (Cambridge: Cambridge University Press).

Hoff, Karla (1998), 'Market Failures and the Distribution of Wealth: A Perspective from the Economics of Information', in Samuel Bowles and Herbert Gintis, with Erik Olin Wright, eds, Recasting Egalitarianism: New Rules for Communities, States and Markets (London: Verso), 332-57.

Honoré, Anthony (1987), 'Ownership', in Anthony Honoré, ed., Making Law Bind (Oxford: Oxford University Press), 161-92.

Hsieh, Nien-hê (2005), 'Rawlsian Justice and Workplace Republicanism', Social Theory and Practice, 31(1), 115-42.

Locke, John 1965 [1690]), The Second Treatise of Civil Government, ed. Peter Laslett (New York: Mentor).

Meade, James (1989), Agathotopia: The Economics of Partnership (Aberdeen: University of Aberdeen).

Mill, John Stuart (1970 [1848], Principles of Political Economy, ed. Donald Winch, (Harmondsworth: Penguin).

Murphy, Liam and Nagel, Thomas (2002), The Myth of Ownership: Taxes and Justice (Oxford: Oxford University Press).

Nozick, Robert (1974), Anarchy, State, and Utopia (Oxford: Blackwell). 


\section{Liberal Philosophies of Ownership}

(p. 38) Nussbaum, Martha (2006), Frontiers of Justice: Disability, Nationality, Species Membership (Cambridge, MA: Harvard University Press).

Otsuka, Michael (2003), Libertarianism Without Inequality (Oxford: Oxford University Press).

Paine, Thomas (1987 [1797]), 'Agrarian Justice', in Isaac Kramnick and Michael Foot eds, The Thomas Paine Reader (Harmondsworth: Penguin), 471-89.

Pateman, Carole (1970), Participation and Democracy (Cambridge: Cambridge University Press).

Rawls, John (1987 [1797]), A Theory of Justice: Revised Edition (Cambridge, MA: Harvard University Press).

Rawls, John (2001), Justice as Fairness: A Restatement (Cambridge, MA: Harvard University Press).

Sen, Amartya (1982), 'Rights and Agency', Philosophy and Public Affairs, 11(2), 3-39.

Steiner, Hillel (1994), An Essay on Rights (Oxford: Blackwell).

Tomasi, John (2012), Free Market Fairness (Princeton: Princeton University Press).

Vallentyne, Peter and Steiner, Hillel, eds (2000), Left-Libertarianism and its Critics: The Contemporary Debate (Basingstoke: Palgrave).

Van Parijs, Philippe (1995), Real Freedom for All: What (if Anything) Can Justify Capitalism? (Oxford: Oxford University Press).

Weitzman, Martin (1984), The Share Economy: Conquering Stagflation (Cambridge, MA: Harvard University Press).

Wolff, Jonathan (1991), Robert Nozick: Property, Justice and the Minimal State (Oxford: Blackwell).

\section{Notes:}

$\left({ }^{1}\right)$ Locke argues that in a non-monetary economy these conditions impose a significant limit on the size of individual holdings and, thus, on inequality in holdings. However, Locke also argues that the introduction of money allows for the legitimate emergence of much larger, and significant inequality in, holdings (Locke 1965: Chapter V, Sections 36$51)$.

$\left({ }^{2}\right)$ As Jonathan Wolff points out, there is an ambiguity as to whether Nozick's criterion is captured by either the question (a) 'Does this act of appropriation make anyone worse off than in a world where this specific resource remained unowned?'; or, (b) 'Does this act of appropriation make anyone worse off than in a world where all external resources remain 


\section{Liberal Philosophies of Ownership}

unowned?' Wolff argues that Nozick probably means to apply the latter test. See Wolff 1991: 112 .

$\left({ }^{3}\right)$ Nozick references the familiar arguments that worker-owned co-operatives will (a) invest less than equivalent capitalist firms because worker-owners lacking individual, transferable property rights in the enterprise will demand that capital outlays repay themselves over a shorter time horizon than an equivalent capitalist firm; and (b) restrict output and employment relative to a capitalist firm because worker-owners have an incentive to fix output to maximize average, rather than total, profit.

$\left.{ }^{4}\right)$ By 'worker-owned firm' here, I mean a firm in which workers have individual shares which they can trade on leaving the enterprise. Bowles and Gintis argue that firms of this kind are more effective in motivating workers, leading to higher labour efficiency than equivalent capitalist firms.

(5) For a fuller account, see J. Cohen 2009.

$\left({ }^{6}\right)$ For relevant critical discussion of self-ownership, see Christman 1991 and G. A. Cohen 1995: Chapters 9 and 10. In terms of Honoré's framework, one might say that Rawls and other democratic liberals do assert a principle of self-ownership but one that involves fewer 'incidents' of private ownership than the libertarian conception, e.g. affirming the incident of 'management' but not that of 'income'.

$\left({ }^{7}\right)$ See Freeman 2007: 106. Rawls abstracts from the issues of health and disability. For helpful critical discussion on this point, see Nussbaum 2006: Chapter 2.

${ }^{8}$ ) Empirical research suggests the impact of workplace democracy on wider political capacity and participation is complex. See Carter (2006) for a helpful overview.

$\left({ }^{9}\right)$ For an important statement of the relational aspects of equality and social justice, focusing on status and power rather than the distribution of income and wealth, see Anderson 1999.

\section{Stuart White}

Stuart White Tutorial Fellow in Politics at Jesus College, Oxford 